\title{
Investment Climate and Foreign Direct Investment Trends in the South Caucasus and Central Asia
}

\section{Slavica Penev}

\section{Abstract}

This paper analyzes and compares investment climates and trends in the South Caucasus and Central Asia. The analyses and comparisons were conducted in view of the impacts of transitional progress, economic development, and the energy reserves from these regions on the inflow of foreign direct investment. Improvement of the investment climate by accelerating the transition process and reducing investment risks can be seen as the most important determinants of FDI inflows into the countries of these two regions. Structural diversification of South Caucasian and Central Asian natural resource-based economies would be essential in ending dependence on the energy and mining sectors and would have positive long-term effects on economic growth and the investment climate, and attract other, additional types of FDI.

JEL: F21

DOI: $10.2478 / v 10033-007-0013-1$

\section{Introduction}

Central Asia and the South Caucasus are regions with strong development potential based on the availability of energy and natural resources, an educated work force, technological infrastructure and strategic geographic location. Yet since their independence the countries of these regions have faced major challenges: the heritage of a centrally planned system, lack of integration into the world economy, weak institutional development, the absence of trade and infrastructure links within the region, and the slow pace of reforms designed to promote governance and private sector development. Progress has been uneven concerning the modernization of their economies. Institutional capacities have not followed the pace of new legislation and there is still a perception of high risk for business transactions. Up to now there was no coherent strategy to enhance regional cooperation. Bilateral and multilateral institutions are active in these regions, but their efforts are largely carried out on an individual country basis.

\section{Macroeconomic performance in the South Caucasus and Central Asia}

The South Caucasus and Central Asian regions comprise the poorest and least developed republics of the former Soviet Union. They gained independence after the break-up of the Soviet Union in the second half of 1991.
The South Caucasus is a small region with about 16 million people, a total GDP of approximately US\$23.9 billion and GDP per capita of US\$ 1.478. It consists of three small countries, Armenia, Azerbaijan and Georgia, each with similar levels of economic development (table 1).

Central Asia is a large territory with low population density. Its population of 59.2 million inhabits an area that exceeds the size of Western Europe. Its total GDP is about US\$ 81.3 billion, while its average GDP per capita is US\$1.408. The five Central Asian countries, Kazakhstan, the Kyrgyz Republic, Tajikistan, Turkmenistan and Uzbekistan, differ substantially in terms of size, population and level of economic development. With a GDP per capita of app. US\$3.700, Kazakhstan is the most developed country of the region, while GDP per capita in the other four countries varies from US\$ 1.283 in Turkmenistan to US\$ 356 in Tajikistan (table 1).

*Penev : Economics Institute Belgrade

Kralja Milana 16, 11.000 Belgrade, Serbia

E-mail:spenev@ecinst.org.yu, penev@eunet.yu 


\begin{tabular}{|l|r|r|r|r|r|r|}
\hline & $|r| r \mid$ & \\
\hline
\end{tabular}

Source: EBRD Transition Report 2006; World Bank WDR 1995 and 2007.

Table 1.

Basic indicators for South the Caucasus and Central Asia

The South Caucasus was strongly affected by ethnic conflicts during and after the break up of Soviet Union, while Central Asia experienced less dramatic consequences from its disintegration.

All the countries from these two regions underwent extremely difficult conditions in the early years of their independence and post-communist political and economic transformation. They inherited ineffective, fragmented, low-income command economies and disrupted productive, financial and trade links.

The South Caucasus went through a deeper recession than any other transitional region. The recession lasted until 1995 and was marked by a drastic decline in GDP and investment. The regional GDP in 1995 stood at only 33 percent of its 1989 level, with an investment rate of only 11.9 per cent of the regional GDP (charts 1,2 and 3).

A certain level of political stabilization of the region resulted in the acceleration of the transition process in the mid 1990s, and has been followed by an intensive growth in investment and GDP (chart 1 and 3). Despite permanent and intensive GDP growth since 1996 (8.9\%), the regional GDP in 2006 stood at 86 per cent of its 1989 level.

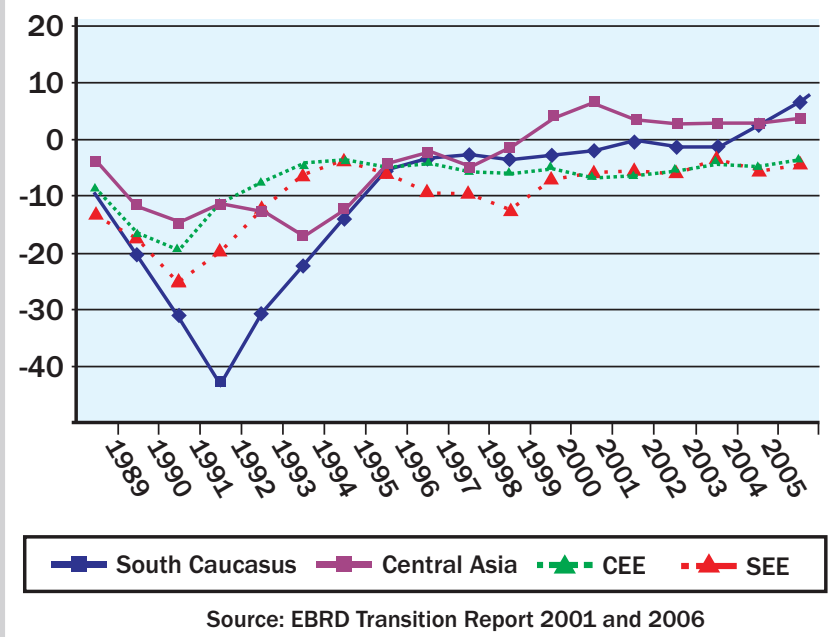

\section{Chart 1.}

Real GDP Growth, 1989-2006 (in \%)

Central Asia experienced a gradual but longer transitional recession. It resulted in the contraction of regional GDP in 1995 to 64 per cent of the region's pre-transition GDP, while its investment rate in 1994 was 17.2 percent of the regional GDP.

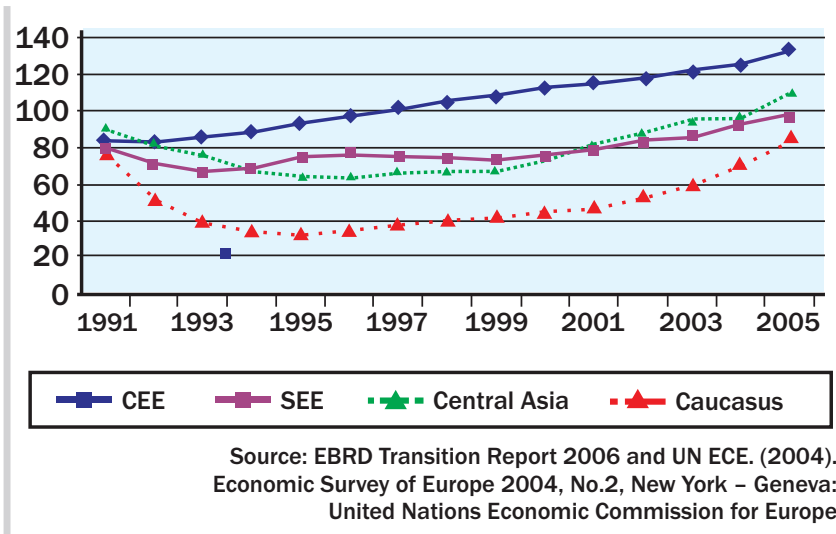

\section{Chart 2.}

Real GDP growth by region, 1990-2005, $(1989=100)$

The region achieved a certain level of liberalization and macroeconomic stabilization in 1999, followed by accelerated growth and intensified investment activity during the last seven years, with an average GDP growth rate exceeding 8 per cent, and investment rates of about 23.5 per cent of GDP. Such favorable trends resulted in complete recovery of the pre-transition levels of regional GDP, which in 2005 stood at 111 per cent of its 1989 level. (charts 1, 2 and 4).

The South Caucasus has been characterized by a consistent savings - investment gap (chart 3), not only due to a low level of domestic savings during the 1990s, insufficient to cover even the low investment rates from that period, but from continuously increasing investment rates over the last several years as well. 

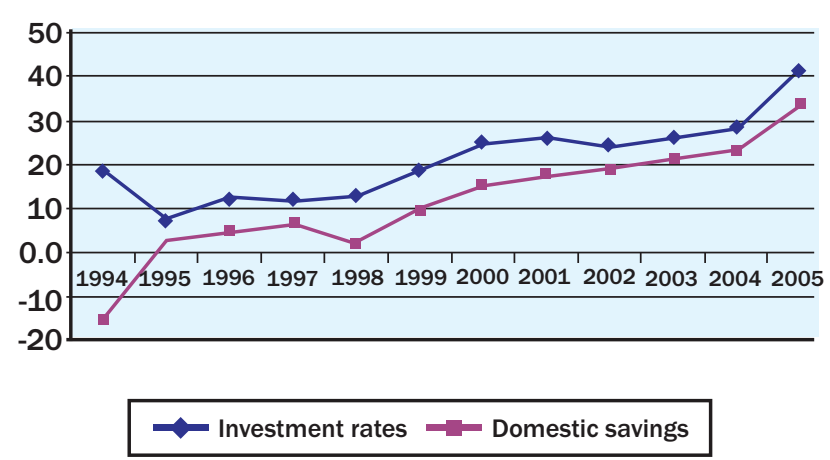

Source: World Development Report various years, WWW database, EBRD database, National statistics

Chart 3.

The South Caucasus, Savings - investment gap, 1994-2005

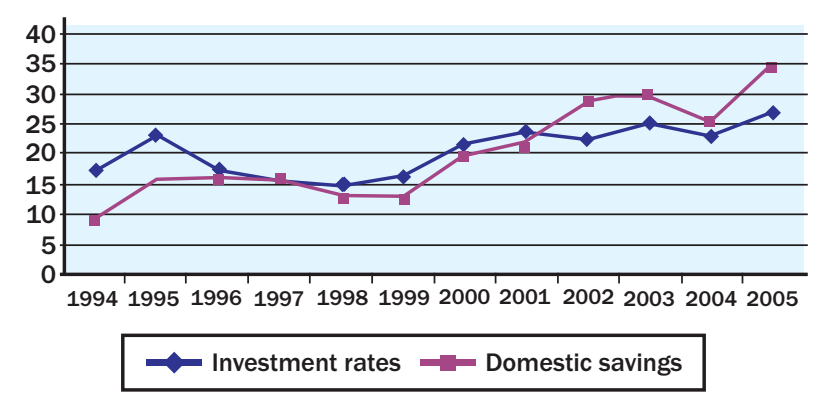

Source: World Development Report various years, WWW database, EBRD database, National statistics

Chart 4.

Central Asia, Savings - investment gap, 1994-2005

In Central Asia the savings - investment gap accrued only periodically, and was much smaller in comparison with the South Caucasus.
Energy-rich countries, such as Azerbaijan and Kazakhstan, have much higher domestic savings due to attracting significant FDI in the energy sector. Consequently, they are registering consistent growth in energy-related revenues.

\section{Foreign Direct Investment and other Capital Inflows into the South Caucasus and Central Asia}

Foreign capital inflows have been of crucial importance for the initiation and acceleration of the transition processes in the countries of the South Caucasus and Central Asia. These inflows played an important role in filling the significant savings - investment gap, since low domestic savings in the early years of transition were a limiting factor for more intensive investment activity in the region, the necessary precondition for accelerated progress in transition and economic performance for both regions.

Official inflows have been unevenly distributed across these two regions. South Caucasian countries received a relatively modest amount of official capital in the early 1990s, but since 1995 their inflows radically increased, providing these countries with additional capital during the extremely difficult period of their political and economic transformation. Since 2000, Azerbaijan has received the predominant part of this capital. In Armenia its inflow has consistently decreased, while in Georgia outflow has been exceeding inflow.

The South Caucasus received more official capital in absolute and per capita terms than Central Asia.

\begin{tabular}{|c|c|c|c|c|c|c|c|c|c|c|c|c|}
\hline Country & 1992 & 1993 & 1994 & 1995 & 1996 & 1997 & 1998 & 1999 & 2000 & 2001 & 2002 & 2003 \\
\hline Armenia & 0 & 0 & 0 & 118 & 168 & 131 & 118 & 92 & 99 & 78 & 74 & 65 \\
\hline Azerbaijan & 0 & 103 & 54 & 182 & 50 & 88 & 68 & 184 & 207 & 163 & 226 & 355 \\
\hline Georgia & 0 & 0 & 17 & 40 & 160 & 137 & 67 & 21 & -98 & -22 & -65 & -43 \\
\hline The South Causacus & 0 & 103 & 71 & 340 & 378 & 356 & 253 & 297 & 208 & 219 & 234 & 378 \\
\hline Kazakhstan & 0 & -33 & 525 & 473 & -206 & -178 & 601 & -33 & -369 & -866 & 238 & -1237 \\
\hline Kyrgyz Republic & 0 & 61 & 14 & 250 & 358 & 0 & 0 & 8 & -3 & 6 & 13 & -9 \\
\hline Uzbekistan & 34 & 810 & -139 & 215 & 511 & -311 & 202 & 144 & 86 & 110 & 147 & 202 \\
\hline Cental Asia & 34 & 838 & 400 & 938 & 663 & -489 & 803 & 119 & -286 & -751 & 398 & -1044 \\
\hline SEE & 724 & 365 & 1064 & 815 & 1397 & 1269 & 808 & 852 & 1117 & 754 & 1545 & 1129 \\
\hline
\end{tabular}

Source: IMF WEO database.

Table 2.

Total official inflows, net (in million USD) 
South Caucasian countries received a relatively modest amount of official funding in the early 1990s. This substantially increased in 1995 and eventually stabilized at an average inflow of 300 million per year over the past ten years (Table 2).

Central Asia received a considerable amount of official capital until 1996. Since 1997, however, this capital played an important role only in Uzbekistan, where official capital still exceeds the level of its FDI inflow.

Due to their poor investment climate as a result of high political risks and a slow progress in transition, these two regions experienced a low level of FDI inflows during the early 1990s.

Along with some progress in transition and political and macroeconomic stabilization, FDI inflows have accelerated and in 1996 significantly surpassed the inflow of official funding into both regions. The FDI into the South Caucasus and Central Asia has been mainly "resource seeking," as most of these countries are rich in natural resources or are transit routes for strategic oil and natural gas export pipeline routes.

FDI inflows into the South Caucasus in the early 1990s were practically non-existent due to high investment risks related to ethnic conflicts, poor progress in transition and macroeconomic instability.

Nevertheless, a certain level of political and economic stabilization of the region achieved in 1995 resulted in the acceleration of FDI inflows in the second half of 1990s, mostly related to FDI in Azerbaijan's energy sector and the construction

\begin{tabular}{|c|c|c|c|c|c|c|c|c|c|c|c|c|c|c|}
\hline Country & 1993 & 1994 & 1995 & 1996 & 1997 & 1998 & 1999 & 2000 & 2001 & 2002 & 2003 & 2004 & 2005 & $\begin{array}{l}2006 \\
\text { Proje- } \\
\text { ction }\end{array}$ \\
\hline Armenia & 1 & 8 & 25 & 18 & 52 & 221 & 122 & 104 & 70 & 111 & 121 & 217 & 255 & 220 \\
\hline Azerbaijan & 0 & 22 & 330 & 627 & 1115 & 1023 & 510 & 149 & 299 & 1048 & 2353 & 2351 & 458 & -2124 \\
\hline Georgia & 0 & 8 & 6 & 54 & 236 & 221 & 62 & 153 & 80 & 130 & 335 & 503 & 415 & 390 \\
\hline Causacus & 1 & 38 & 361 & 699 & 1403 & 1465 & 694 & 406 & 449 & 1289 & 2809 & 3071 & 1128 & -1514 \\
\hline Kazakhstan & 473 & 635 & 964 & 1137 & 1320 & 1143 & 1468 & 1278 & 2861 & 2463 & 2210 & 5548 & 1721 & 2500 \\
\hline Kyrgystan & 10 & 38 & 96 & 47 & 83 & 87 & 38 & -7 & -1 & 5 & 46 & 131 & 101 & 89 \\
\hline Tajikistan & 9 & 12 & 10 & 18 & 18 & 25 & 21 & 24 & 9 & 36 & 32 & 272 & 36 & 60 \\
\hline Turkmenistan & 79 & 103 & 233 & 108 & 108 & 62 & 125 & 131 & 170 & 276 & 226 & 330 & 320 & 300 \\
\hline Uzbekistan & 48 & 73 & -24 & 90 & 167 & 140 & 121 & 75 & 83 & 65 & 70 & 189 & 211 & 250 \\
\hline Central Asia & 619 & 861 & 1278 & 1400 & 1696 & 1457 & 1773 & 1501 & 3122 & 2845 & 2584 & 6470 & 2389 & 3199 \\
\hline SEE & 274 & 645 & 725 & 1148 & 2921 & 3974 & 3618 & 3628 & 4302 & 3587 & 8219 & 12023 & 13011 & 19345 \\
\hline CEE & 3925 & 4580 & 11422 & 10023 & 11217 & 15098 & 18329 & 19689 & 17497 & 21504 & 8417 & 23147 & 27509 & 22071 \\
\hline
\end{tabular}

Source: EBRD Transition Report 2003 and 2006

Table 3.

FDI inflows, 1993- 2006 (in million US\$)

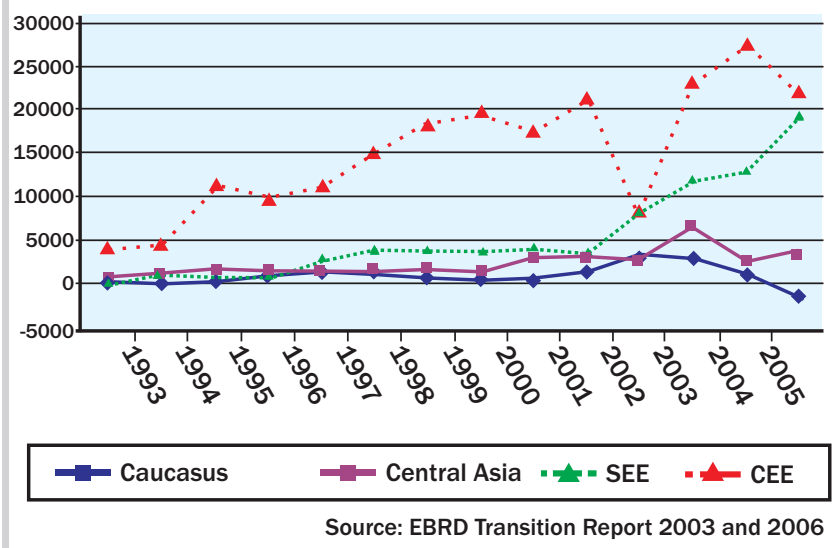

Chart 5.

FDI inflows, 1993- 2006 (in million US\$)

of an oil pipeline linking the Caspian Sea in Azerbaijan with the Georgian Black Sea port of Supsa, the first among a number of huge investments in the South Caucasus energy transport infrastructure. Due to this energy-related FDI and several large privatizations (Tbilisi electric power distribution system, Armentel, etc), the regional FDI in 1998 amounted to almost US\$ 1.5 billion. After a period of stagnation and even decline (1999-2001), FDI inflows in the South Caucasus accelerated between 2001-2004, recording maximum levels in 2004 due mostly to two big regional projects related to the construction of oil and gas pipelines in Azerbaijan and Georgia (Shiells, R. Clinton, 2003).

The construction of the Baku-Tbilisi-Ceyhan (BTC) oil pipeline, which started in early 2003 and was completed in 2005, has

been the most important infrastructure project in the region. 
The direct investment in its construction amounted to US\$3.6 billion, with an enormous amount of capital invested in related projects. The pipeline's route extends from Baku, via Tbilisi in Georgia, to Ceyhan on the Turkish Mediterranean coast, providing easier access to Azeri oil and creating the possibility for this pipeline to extend and connect to the Kazakhstan Caspian region oil fields.

The South Caucasus gas pipeline (Baku-Tbilisi-Erzurum), constructed parallel to the BTC from Azerbaijan through Georgia to the Turkish-Georgian border, where it will connect the Turkish gas network, is estimated to cost about US\$ 1 billion. From 2007, it will export natural gas from Azerbaijan.

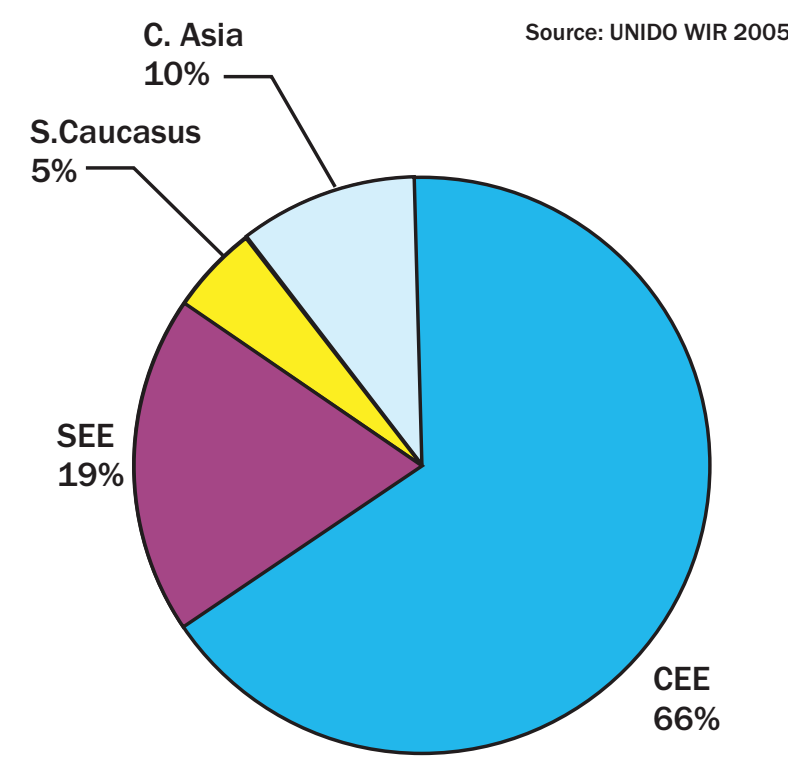

Chart 6.

FDI stock per region, 2005

Most Central Asian FDI has been in Kazakhstan - specifically in the extraction and transport of oil and gas from the Caspian region fields. The development of the three major oil fields in Kazakhstan (Tengiz, Karachaganak and Kashagan) has given rise to an influx of new investment and infrastructure development.

After the finalization of huge FDI energy-related projects in Azerbaijan and Kazakhstan, FDI radically decreased in both regions in 2005. It is estimated that in 2006 the South Caucasus will record negative FDI inflows, due to an outflow of FDI from Azerbaijan of more than US\$2.0 billion.

The regional distribution of FDI among South Caucasian countries has been unequal (table 3 and chart 7), as Azerbaijan, the only energy-rich South Caucasian country with significant oil and gas reserves, attracted about 74 per cent of the regions' FDI. Even though Georgia is not rich in natural resources, the country benefited a great deal from its important geographic position as a transit point linking the energy-rich Caspian region with Europe. The three large pipelines- BTC, SCP and Baku-Supsa- traverse Georgia and have strongly affected the level of FDI in the country, with record levels of US\$ 503 million in 2004 and US\$ 415 million in 2005. On the other hand, Armenia attracted about 10 per cent of the regional FDI, most of it related to privatization.

Source: UNIDO WIR 2006, EBRD Transition Report 2006

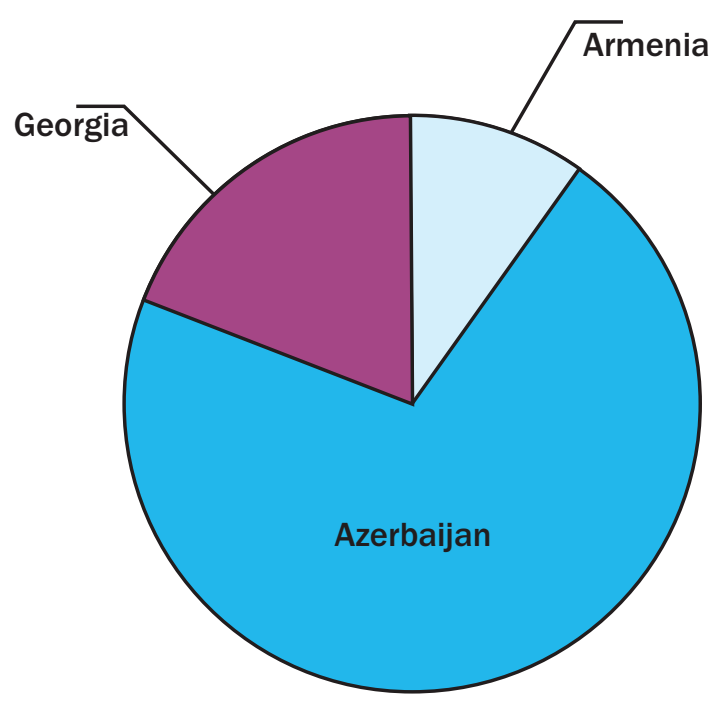

Chart 7.

The South Caucasus FDI stock breakdown by country, in 2005

FDI inflows in Central Asia have been more intensive in the early 1990s compared to the South Caucasus. Their growth was relatively stable, without severe setbacks. These inflows have been highly concentrated (chart 8), as 83 per cent of the regional FDI went to Kazakhstan, the one country with significant oil and natural gas reserves. Kazakhstan's FDI stock is the largest among all the countries from these two regions, while Tajikistan has the smallest.

Most of Kazakhstan's FDI has been invested in the extraction and transport of oil and gas from the Caspian region fields. The development of the three major oil fields in Kazakhstan (Tengiz, Karachaganak and Kashagan) has given rise to an influx of new investment and infrastructure development. In addition to FDI in the oil and gas sector, Kazakhstan attracted considerable foreign participation in the extraction of other natural resources, as well as in power, telecom and other public utilities sectors.

Turkmenistan attracted a lesser - though still considerable - amount of FDI, primarily in its energy sector.

Uzbekistan is a country rich in natural resources, such as natural gas, gold, silver, copper, oil and uranium, and is one of 
the top ten natural gas-producing countries in the world, but still lags far behind Kazakhstan and even Turkmenistan in terms of FDI inflow. Uzbekistan's leading oil and natural gas projects are significantly smaller and markedly less developed than those in Kazakhstan.

The Kyrgyz Republic received relatively modest FDI inflow, mostly in the Kumtor gold mine.

Source: UNIDO WIR 2006, EBRD Transition Report 2006.

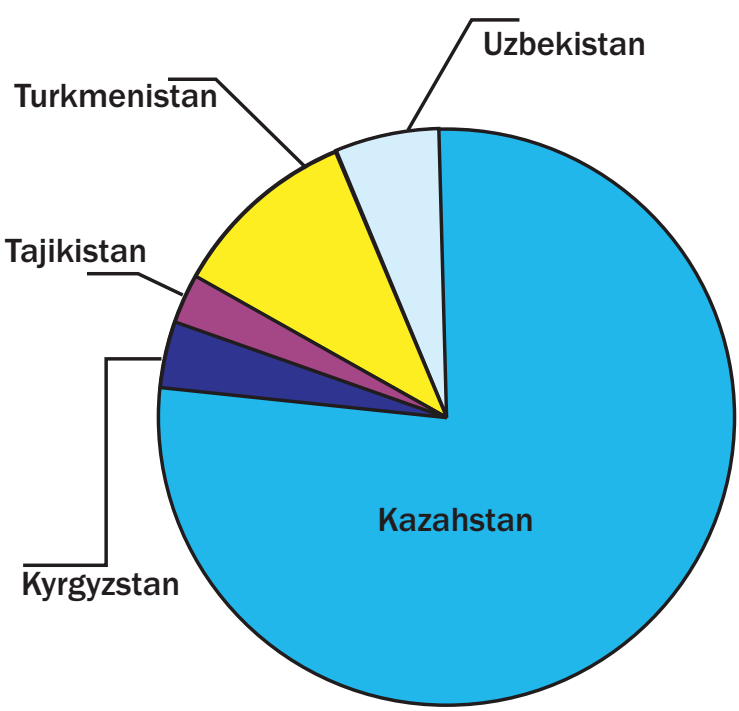

Chart 8.

Central Asia FDI stock breakdown by country, in 2005

The unstable political situation in Tajikistan was one of the main reasons for its very low level of FDI.

The FDI stock per capita in South Caucasus and Central Asia was US\$ 851 and 482, respectively (Chart 9). However, the differences among the countries from these two regions were much more extensive, varying from US\$ 1.225 and US\$ 1.568 in energy-rich countries such as Azerbaijan and Kazakhstan, to only US\$ 51 in Uzbekistan.

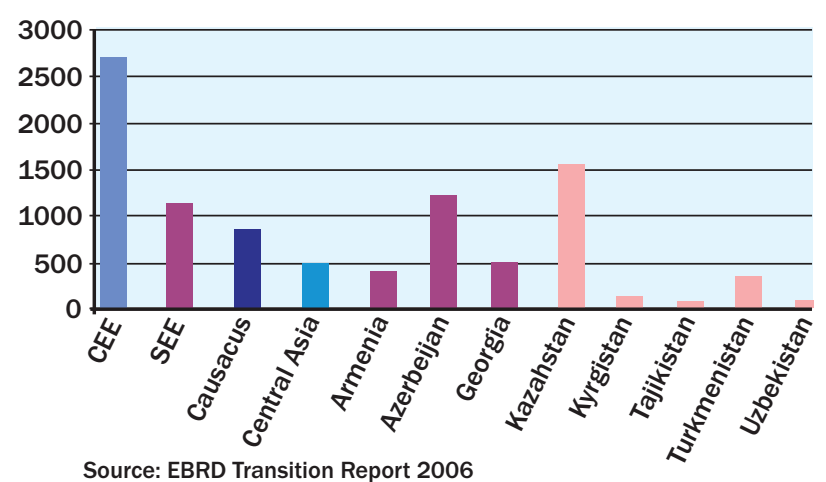

Chart 9.

FDI Stock per capita, 2005 (in US\$)
In terms of FDI stock per GDP, there are enormous differences between and within the regions. The FDI inward stock per GDP in Central Asia and South Caucasus by the end of 2005 was $34.2 \%$ and $74.5 \%$, respectively. The differences among the individual countries varied from $110.5 \%$ in Azerbaijan to only 8.2\% in Uzbekistan (Chart 10).

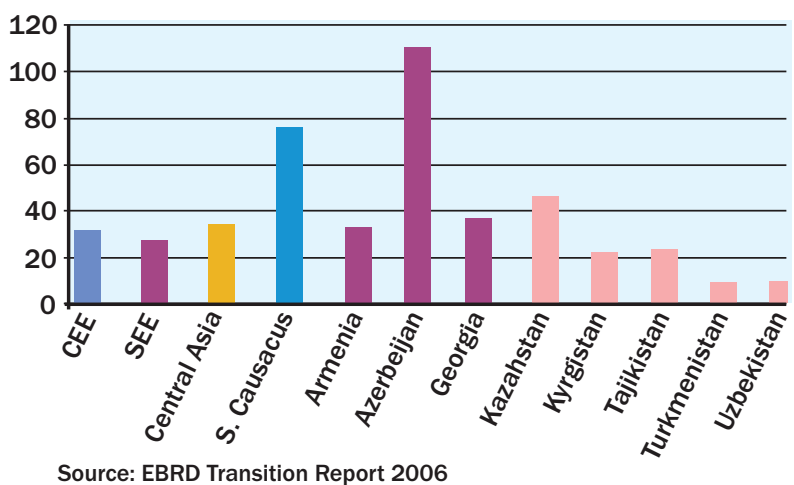

Chart 10.

Inward FDI Stock as a Percentage of GDP, 2005

\section{Investment climate in the South Caucasus and Central Asia}

The South Caucasus and Central Asia have several advantages for attracting FDI, and their identification is important for the development of their FDI strategies. In spite of some differences between the regions, they have a number of similar advantages important for attracting private foreign capital.

The most important advantages for attracting FDI into the South Caucasus are:

Endowment in natural resources as a potential for further resource related FD/;

Cheap and productive labor;

Internal and external liberalization;

Achieved macroeconomic stabilization, high growth rates and good prospects for long term sustainable growth;

FDI in energy infrastructure as a catalyst for other related FDI (Azerbaijan and Georgia).

The predominant part of FDI in this region has been resource-seeking, mostly invested in energy production/extraction (Azerbaijan) and energy export infrastructure (Azerbaijan and Georgia). As the region's energy reserves are mostly located in Azerbaijan, this country has good prospects for attracting 
foreign capital for the further development of its Caspian oil and natural gas fields. In addition to the South Caucasus gas pipeline, which is almost finalized, new investment in the energy export infrastructure can be expected, including the extension of the BTC pipeline and its connection with Kazakhstan's oil fields in the Caspian Sea region.

FDI in energy extraction and energy infrastructure has already been a catalyst for related FDI (Azerbaijan and Georgia), with especially positive effects on the development and growth of the construction and service sectors.

In spite of the importance of the energy sector, which has the potential for further inflows, economic diversification remains a challenge for attracting investment. One of the region's comparative advantages is the availability of cheap and productive labor. The labor costs in this region are much lower, not only in comparison to CEEB - new EU member countries - but in comparison to SEE countries as well. In addition to low labor costs, macroeconomic stabilization, growth prospects and economic liberalization are important preconditions for attracting export-oriented, labor-intensive FDI.

Due to its favorable strategic position, the South Caucasus is becoming an important link between East and West, not only as a corridor for oil supply from Caspian oil fields, but as a region that will connect the trade and transport routes between East and West, thus making a significant contribution in terms of strengthening regional cooperation and boosting prosperity.

The most important advantages for attracting FDI into Central Asia are:

\section{- Endowment in natural resources as a potential for further} resource-related FDI;

- High growth rates;

- Huge FDI in the energy sector as a catalyst for other related FDl;

\section{- Cheap and productive labor.}

Central Asia is endowed with abundant natural resources, including oil, natural gas, coal and metal ores. These resources are unequally distributed across the countries of this region. Kazakhstan is an energy-rich country with huge reserves of oil and natural gas, but is also rich in coal, iron, chrome, gold and other metal ores. Uzbekistan and Turkmenistan are rich in natural gas and coal and have some reserves of oil. The Kyrgyz Republic is rich in gold and hydropower, while Tajikistan, in addition to hydropower, has some reserves of uranium, petroleum, coal, gold and silver.

Huge FDI in the energy sector and other extraction industries can be a catalyst for other related FDI, with important multiple effects for economic development in the region.

Cheap and productive labor, high growth rates and some progress in transition can be considered a good precondition for attracting more diversified, labor-intensive FDI. Nevertheless, this can only be considered a potential advantage, due to a number of barriers for the realization of these advantages, including poor physical infrastructure and lack of regional cooperation.

\section{Barriers to FDI inflows in the South Caucasus and Central Asia}

Despite the differences between the South Caucasus and Central Asia, and their constituent countries, they share a number of similar obstacles that adversely affect the quality of their investment climates.

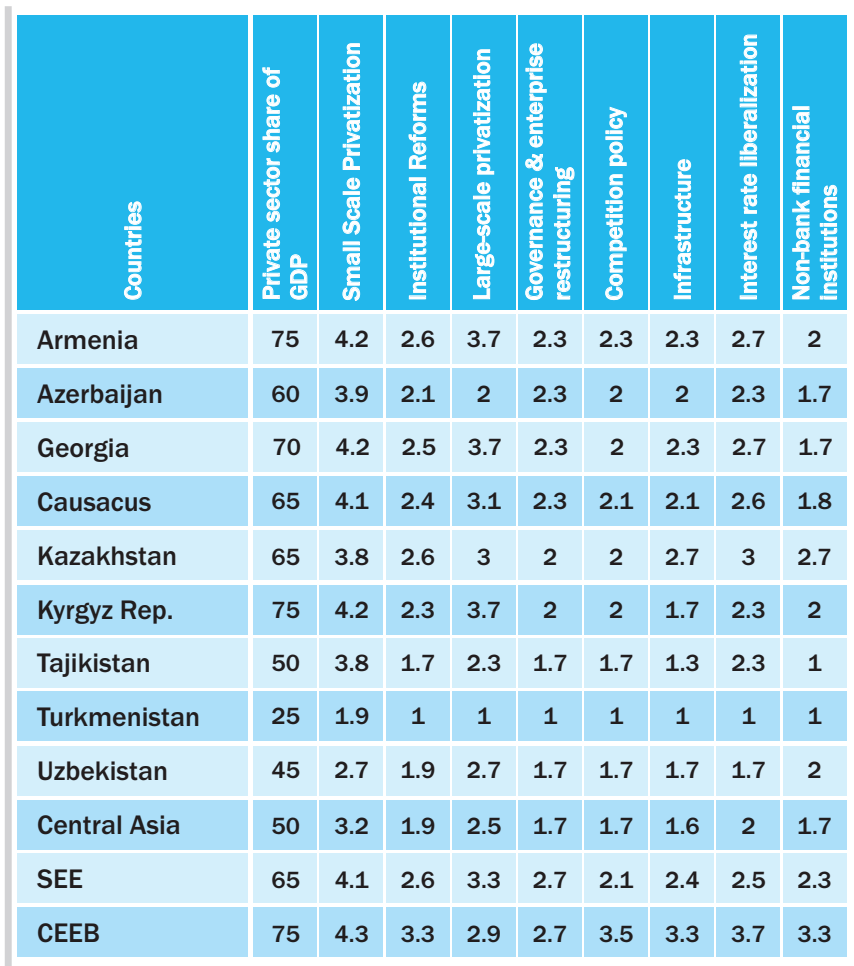

Source: EBRD 2006.

Note 1: Ranging from minimum 1 = no or little progress to

maximum $4+=$ standards of advanced industrial economies.

Table 4.

EBRD transition indicators, 2006 
Experience shows that similar barriers to FDI inflows are more or less present in both regions:

High investment risks;

Underdeveloped institutional infrastructure due to slow progress in institutional reforms;

Underdeveloped physical infrastructure;

Unfavorable legal environment-governance and corruption problems;

Weak regional cooperation;

Relatively small size of domestic markets and low pur chasing power.

Even though relatively high investment risks characterize the countries of both regions, they are more severe in South Caucasian countries due to unsolved political and territorial disputes still present in the region. Since private foreign capital is very sensitive to security and the general political environment, it is crucial for these countries to find peaceful solutions to existing political tensions. This is an important precondition for regional cooperation.

\begin{tabular}{|c|c|c|c|c|c|c|}
\hline$\frac{d}{\frac{1}{2}}$ & $\begin{array}{l}\frac{9}{2} \\
\frac{8}{3} \\
\frac{2}{2} \\
\frac{5}{5} \\
\frac{5}{2} \\
\text { 을 }\end{array}$ & 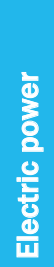 & $\frac{\frac{3}{30}}{\frac{3}{d 0}}$ & $\frac{n}{\frac{0}{0}}$ & $\begin{array}{l}\frac{9}{0} \\
\frac{8}{8} \\
\frac{8}{5} \\
\frac{8}{3} \\
\frac{8}{8} \\
\frac{8}{6}\end{array}$ & 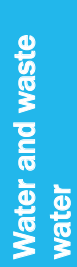 \\
\hline Armenia & 2.3 & 3.3 & 3.0 & 2.3 & 2.7 & 2.0 \\
\hline Azerbaijan & 2.0 & 2.3 & 2.3 & 2.3 & 1.7 & 2.0 \\
\hline Georgia & 2.3 & 3.0 & 3.0 & 2.0 & 2.7 & 2.0 \\
\hline S. Causacus & 2.2 & 2.9 & 2.4 & 2.2 & 2.1 & 2.0 \\
\hline Kazakhstan & 2.7 & 3.3 & 3.0 & 2.0 & 3.0 & 2.0 \\
\hline Kyrgyz Rep. & 1.7 & 2.3 & 1.0 & 1.0 & 3.0 & 1.7 \\
\hline Tajikistan & 1.3 & 2.0 & 1.0 & 1.0 & 2.3 & 1.0 \\
\hline Turkmenistan & 1.0 & 1.0 & 1.0 & 1.0 & 1.0 & 1.0 \\
\hline Uzbekistan & 1.7 & 2.3 & 1.7 & 1.0 & 2.0 & 1.7 \\
\hline Central Asia & 1.7 & 2.7 & 1.5 & 1.2 & 2.3 & 1.5 \\
\hline SEE & 2.4 & 3.0 & 2.7 & 2.4 & 2.9 & 2.2 \\
\hline CEEB & 3.2 & 3.3 & 3.3 & 2.8 & 3.4 & 3.2 \\
\hline
\end{tabular}

Source: EBRD 2006.

Note 1: Ranging from minimum 1 = no or little progress to

maximum $4+=$ standards of advanced industrial economies.

Table 5.

EBRD infrastructure transition indicators, 2006
Slow progress in institutional reforms in the South Caucasus and Central Asia still poses a serious problem (Table 4). Weak institutional infrastructure, lack of entrepreneurial capacity and lack of competition policy in both regions are generating a number of obstacles for the improvement of the business and investment environment, and are crucial impediments to private sector development and long term prosperity.

Physical infrastructure is underdeveloped in both regions. All Central Asian countries, with the exception of Kazakhstan, are lagging far behind other countries in transition in almost all utilities sectors. A lack of adequate roads, export energy infrastructure and railways, and the poor quality of existing ones, together with inadequate water supply, are important obstacles to FDI in Central Asia. Inadequate export energy infrastructure is a serious impediment to increased gas production and exports not only in Uzbekistan, but also from other Central Asian countries rich in natural gas, such as Kazakhstan and Turkmenistan.

Weak institutions present an obstacle to good governance, resulting in poor implementation of laws, development of informal processes and widespread corruption in both regions.

Transparency International's Corruption Perception Index identifies high levels of corruption throughout the South Caucasus and Central Asia, greatly exceeding corruption levels in CEE and SEE countries (Table 6).

\begin{tabular}{|c|c|c|}
\hline Country rank 2005 & Country & CPI 2005 score \\
\hline 93 & Armenia & 2.9 \\
\hline 130 & Azerbaijan & 2.4 \\
\hline 99 & Georgia & 2.8 \\
\hline & The South Caucasus & 2.7 \\
\hline 111 & Kazakhstan & 2.6 \\
\hline 130 & Kyrgyzstan & 2.2 \\
\hline 93 & Tajikistan & 2.2 \\
\hline 130 & Turkmenistan & 2.2 \\
\hline 93 & Uzbekistan & 2.1 \\
\hline & Central Asia & 2.3 \\
\hline & SEE & 3.1 \\
\hline & CEEB & 5.1 \\
\hline
\end{tabular}

Source: Transparency International's Corruption Perception Index,2006. Note 1: CPI 2006 score relates to perceptions of the degree of corruption as seen by business people, academics and risk analysts, and ranges between 10 (highly clean) and 0 (highly corrupt).

Table 6.

Transparency International's Corruption Perception Index1, 2006 
Note ${ }^{1}$ : CPI 2006 score relates to perceptions of the degree of corruption as seen by business people, academics and risk analysts, and ranges between 10 (highly clean) and 0 (highly corrupt).

The country rankings range from Armenia in 88th place (out of 168 countries) to Tajikistan in 144th place and Turkmenistan in 155th place. Azerbaijan, Georgia and Kazakhstan have managed to reduce their corruption levels in 2005 in comparison to 2004, while the Kyrgyz Republic and Uzbekistan worsened their positions.

Private foreign capital is sensitive to legal uncertainty, especially to high levels of corruption. The creation of a favorable legal and regulatory environment for business activities is of the utmost significance.

Weak regional cooperation and integration is characteristic of both regions. The disintegration of the Soviet Union resulted in a sharp decline in trade between the former Soviet republics in the early 1990s. While intra-Soviet trade has exceeded 80 percent of the total Soviet trade for the non-Russian republics in 1990, intra-CIS trade accounted for only 33 per cent of the total CIS trade in 1994 and fell further to 25 per cent in 2002 (Elborgh-Woytek, Katrin, 2003). This decline was more dramatic in the South Caucasus than in Central Asia, as the share of their trade with CIS countries in 2002 on average amounted to only 22 per cent, while this share in the Central Asian countries was considerable, and exceeds 45 per cent of their total trade (Kokko, Ari and Patrik Gustavsson, 2004). Trade among the ex-Soviet republics is especially important for the small and landlocked countries of the Central Asian region due to their poor infrastructure and their difficulties integrating into the world market.

The South Caucasus has a history of conflicts that strongly affects regional political and economic cooperation. Apart from political and infrastructural obstacles, a number of institutional, bureaucratic and structural barriers to intra-regional trade and investment exist in the region. The EU has developed a vision of regional cooperation through The Wider Europe Initiative, launched in 2003 by the European Commission. The World Bank, EBRD and other IFIs are active in the region facilitating and re-establishing trade among these countries.

Regional cooperation in Central Asia is jeopardized by its weak institutions, trade barriers and underdeveloped physical infrastructure. An improvement of their intra-regional cooperation, especially on economic issues such as trade, transport infrastructure and investment, would have positive effects on economic growth and inflow of FDI (Linn, Johannes, 2005).
Membership in the WTO is of great importance, not only for trade acceleration and liberalization in general, but also intra-regional trade, reducing the number of tariff and non-tariff barriers among these countries.

\begin{tabular}{|l|c|c|c|}
\hline \multicolumn{1}{|c|}{ Countries } & Applied & \multicolumn{1}{|c|}{$\begin{array}{c}\text { Working } \\
\text { parties }\end{array}$} & Member \\
\hline The S. Causacus & & & Feb. 2003 \\
\hline Armenia & 1995 & & \\
\hline Azerbaijan & 1997 & 4 meetings, 1997-06 & \\
\hline Georgia & 1996 & & June 2000 \\
\hline Central Asia & & & \\
\hline Kazakhstan & 1996 & 8 meetings, 1997-05 & \\
\hline Kyrgyz Republic & 1993 & & 1998 \\
\hline Tajikistan & 2001 & 2 meetings, 2004-05 & \\
\hline Turkmenistan & Not aplicable & & \\
\hline Uzbekistan & 1994 & 3 meetings, 2002-05 & \\
\hline
\end{tabular}

Source: WTO website, www.wto.org

\section{Table 7.}

Status of WTO accession of South Caucasian and Central Asian countries

Accession to the WTO progressed more in the South Caucasus, as Georgia and Armenia are already members of WTO, and Azerbaijan intensified its efforts to speed up the process. This process has been much slower in Central Asia, as at present only the Kyrgyz Republic is a member of WTO. However, Kazakhstan advanced well in the accession process, and has good prospects of becoming a member of the WTO in the near future. Uzbekistan and Tajikistan already started the accession process, but are still lagging behind Kazakhstan. Turkmenistan is the only country that has not applied for WTO membership.

In the last fourteen years a number of bilateral and regional trade agreements have been signed. The Commonwealth of independent states (CIS), created in December 1991, includes all the countries of the former Soviet Union except the Baltic states. The CIS was established to create a regional economic union. Its goals include:

forming a common economic space grounded on the free movement of goods, services, labor force, capital;

coordinating monetary, tax, price, customs, external eco nomic policies;

bringing together methods of regulating economic activity

1 CIS - Commonwealth of independent states which includes all the countries of the former Soviet Union except the Baltic states. 


\section{- creating favorable conditions for the development of direct production relations.}

A number of other regional organizations and trade agreements have been established and signed, mostly related to free trade among the countries of these regions (Central Asian Economic Union -CACO; Economic Cooperation Organization -ECO, CIS, EAEC etc), but these organizations are characterized by weak institutions, and the implementation of these agreements is still at an early phase.

\section{Conclusions}

Improvement of the investment climate by accelerating the transition process and reducing investment risks can be recognized as the most important economic policy related determinants of FDI inflows into the countries of these two regions. However, further progress in regional and international integration and the elimination of widespread corruption through the introduction of integrity programs in the public sector and diminished bribery in business transactions are also important preconditions for accelerating and diversifying FDI inflows.

Structural diversification of South Caucasian and Central Asian natural resource-based economies would be essential in ceasing dependence on the energy and mining sectors and would have positive long-term effects on economic growth, the investment climate and the attraction of other types of FDI in addition to current FDI, which is mostly related to natural resources.

The creation of national funds in natural resourcebased economies, similar to those that already exist in Kazakhstan and Azerbaijan, by saving part of the revenues from oil and other extraction industries, might be used to support institutional reforms and the development of the private sector, and encourage PPPs in the development of the necessary physical infrastructure in all the countries from these two regions.

\section{References}

Babetskii, Ian, Oxana Babetskaia-Kukharchuk and Martin Raiser. (2003). How deep is your trade? Transition and international integration in Eastern Europe and the former Soviet Union, EBRD Working paper 83, London.

EBRD. 2006. Transition Report 2006. London: European Bank for Reconstruction and Development.

EBRD. 2006. Country Strategy - Georgia, /www.ebrd.com
Economist Intelligence Unit (EIU). 2003. World Investment Prospects. 2003 edition. London: E.I.U.

Elborgh-Woytek, Katrin. (2003). Of Openness and Distance: Trade Developments in the Commonwealth of Independent States, 1993-2000, IMF Working Paper 207/2003, Washington.

Georgian economic trends (2006). GEPLAC 2006 No.4. www.geplac.org

Grafe, Clemens, Martin Raiser and Toshiaki Sakatsume. (2005). Beyond borders: Reconsidering regional trade in Central Asia, EBRD Working paper 95, London.

Kessides, N. Ioannis. (2004). Reforming Infrastructure - Privatization, Regulation and Competition, a co-publication of the World Bank and Oxford University Press.

Kokko, Ari and Patrik Gustavsson. (2004). Regional integration, foreign direct investment, and regional development, Volume $9 \mathrm{~N}^{\circ} 12004110$ EIB papers. Luxembourg

Linn, Johannes. (2005) Central Asia Human Development Report: Bringing Down Barriers, UNDP 2005, New York

Loukoianova, Elena and Anna Unigovskaya. 2004. Analysis of Recent Growth in Low-Income CIS Countries. IMF Working Paper/ 04/151 Washington: International Monetary Fund.

Merlevede, Bruno and Koen Schoors. 2004. Determinants of foreign direct investment in transition economies. Ghent: Ghent University. Mimeo.

Morisset, Jacques and Olivier Lumenga Neso. 2002. Administrative Barriers to Foreign Investment in Developing Countries. Washington, D.C.: Foreign Investment Advisory Service (FIAS).

Penev, Slavica. 2004. Progress in transition and foreign direct investment in South East Europe and the South Caucasus. Industrija, 4/2004. Economics Institute Belgrade, December 2004, Belgrade.

Shiells, R. Clinton. (2003). FDI and the Investment Climate in the CIS Countries. IMF Policy Discussion Paper 2003/5. November 2003. Washington.

Steves, Franklin and Alan Rousso.. (2003). Anti-corruption programmes in post-communist transition countries and changes in the business environment, 1999-2002. EBRD Working paper 85, October 2003, London

Transparency International Corruption Perceptions Index 2006, www.transparency.org/

UNCTAD. (2006). World Investment Report 2006. New York and Geneva.

UN ECE. (2004). Economic Survey of Europe 2004, No.2, New York - Geneva: United Nations Economic Commission for Europe. 